\title{
CONSUMERS' PERCEPTIONS OF CORPORATE SOCIAL RESPONSIBILITY IN A DEVELOPING COUNTRY
}

\begin{abstract}
:
Corporate social responsibility (CSR) increasingly receives attentions from managers and researchers, especially in the area of consumer perception and response of CSR. However, most of this research was conducted in the context of developed countries. It shows that research on consumer perception toward CSR in developing countries needs to be developed. This paper will examine consumer perception in the developing country of Indonesia. This research produced mixed results, suggesting that CSR is still a concept waiting to be applied in the developing country. Consumers are often unaware and unsupportive toward corporate social responsibility. This is the opposite finding of consumer perception in developed countries, where most consumers are willing to support CSR launched by corporations. Nevertheless, there is an interesting finding; when consumers have to buy similar products with the same price and quality, CSR could be the determining factor. They would buy from the firm that has a socially responsible reputation.
\end{abstract}

Keywords : Corporate social responsibility, consumer perception, developing country, and Indonesia 


\section{Introduction}

Research on Corporate Social Responsibility (CSR) dates back to the 1930s when Berle and Means advocated to incorporate voting rights for greater transparency and accountability for all shareholders of a company (Berle \& Means, 1948; Carroll, 1991). Nowadays CSR increasingly receives attention from managers and researchers, especially in the area of consumer perception and response of CSR (Beckmann, 2007; Bhattacharya \& Sen, 2004; Smith, 2003). Beckman (2007) summarizes research on consumer perception and response toward CSR and suggests that there are positive relationships between a company's CSR activity and consumers' reactions to that company and its product. However, most of this research was conducted in developed countries (e.g. Brown \& Dacin, 1997; Creyer \& Ross, 1997; Maignan, 2001; Maignan \& Ferrell, 2000; Sankar, Bhattacharya, \& Daniel, 2006; Uusitalo \& Oksanen, 2004). These findings show that research on consumer perception of social responsibility in developing countries needs to be conducted (Jamali, 2007). Visser (2007; p. 474) suggest four rationales for focusing on CSR in developing country as distinct from CSR in the developed world:

(1) developing countries represent the most rapidly expanding economies, and hence the most lucrative growth markets for business; (2) developing countries are where social and environmental crises are usually most acutely felt in the world; (3) developing countries are likely to have the most dramatic social and environmental impacts (both positive and negative); and (4) developing countries present a distinctive set of CSR agenda challenges which are collectively quite different to those faced in the developed world.

Thus, this paper will examine consumer perception of corporate social responsibility in the developing country of Indonesia. Do consumers have a positive perception toward a company's CSR and support its products? Is CSR an appropriate strategy to be used?

\section{Literature review}

\section{Corporate Social Responsibility (CSR)}

A.B. Carroll, one of the pioneers of CSR, defines it as: 
The total corporate social responsibility of business entails the simultaneous fulfilment of the firm's economic, legal, ethical and philanthropic responsibilities. Stated in more pragmatic and managerial terms, the CSR firm should strive to make a profit, obey the law, be ethical, and be a good corporate citizen (Carroll, 1991, p. 43).

Previously Carroll (1979) developed CSR theory with his conceptual model of corporate performance, which is still widely used among CSR scholars. He emphasized that social responsibilities should address the entire range of obligations business has to society. It must embody the economic, legal, ethical and discretionary categories of business performance. To be considered a socially responsible company, Carroll (1979) suggests that companies should follow four components. The first component is economic responsibility. This is the business's fundamental responsibility to make a profit and expand. The second component is legal responsibility. A business has to obey the law and operate within the legal framework of society. The third component is ethical responsibility. A business has to respect the rights of others and meet the expectations applied by society to do what is right, just and fair. The last and highest component is philanthropic responsibility. A business should contribute to and support the broader community and improve the quality of society (Carroll, 1995; Snider, Hill, \& Martin, 2003). Since Carroll's (1979) seminal work, many new definitions of CSR have been proposed. For example, marketing studies have identified CSR as a business entity's adherence to and fulfilment of the responsibilities that could bring benefits to the greater community (Albinger \& Freeman, 2000; Sen \& Bhattacharya, 2001; Carroll, 1991; Dacin \& Brown, 1997). The World Business Council for Sustainable Development (2006) has defined CSR as the continuing commitment by business to behave ethically and to contribute to economic development while improving the quality of life of the workforce and their families as well as that of the local community and society at large; management studies have defined CSR as a company's commitment to operate in an economically and environmentally sustainable way, while recognising the interest of multiple stakeholders and maximising economic, social and environmental values (Matten et al., 2003; Waddock, 2004; Waddock \& Post, 1990; Wood, 1991). Although there is still no agreement on any one 
definition of CSR, each definition is based on the idea that CSR is about how business takes account of its economic, social and environmental impacts in the way it operates.

\section{Consumer perception toward CSR in the developed country}

Developed countries are nations with Gross National Income per capita of $\$ 11,456$ or above (World Bank, 2007). In the context of developed country, many researches suggest positive perception of consumer toward CSR. First, consumers are aware and interested in CSR and consider CSR as a purchase criterion. Some consumers are willing to pay higher price for that firm's products (Creyer \& Ross, 1997; Handelman \& Arnold, 1999). In addition, Hill \& Knowlton/ Harris Interactive poll in 2001 shows that " $79 \%$ of Americans take corporate citizenship into account when deciding whether to buy a particular company's product." Nevertheless, most consumers in the developed countries are still unwilling to compromise CSR on core product attributes such as price and quality (Beckmann, 2007; Cone Corporate Citizenship, 2001). Secondly, CSR increases positive attitude and loyalty towards the company and/ or the brand (Bhattacharya \& Sen, 2004; Brown \& Dacin, 1997; Du, Bhattacharya, \& Sen, 2007; Lichtenstein, Drumwright, \& Braig, 2004) and improved financial performance. A study by Orlitzky, Schmidt, \& Rynes (2003) using a meta-analysis of 52 studies on the relationship between Corporate Social Performance and Corporate Financial Performance, suggesting there is positive relationship with the two. Third, there are national and cultural differences in CSR perception between developed countries. However, it still shows positive perception toward CSR (Maignan \& Ferrell, 2003). Beckmann (2007, p. 32) suggests

'there are cultural differences that suggest a strong influence of the economic, technological, political and social context within which any assessment of the (communication) effects of CSR activities on consumers' responses need to be analysed' 
In the context of developed country, there are cultural differences in consumer perception toward CSR; therefore, we need to investigate if there are differences in consumer perception toward CSR in the context of developing country.

\section{Corporate social responsibility in Indonesia}

CSR research in the developing country mostly analyses the business side of CSR (e.g. Blowfield, 2003; Quazi \& O'Brien, 2000; Zulkiflli \& Amran, 2006), but rarely examined the consumer side of CSR, especially on how consumers respond to CSR. In addition, most research in CSR tends to generalize all developing countries (Frynas, 2006). Thus, we will use Indonesia as the object of our study.

As the fourth most populous nation in the world with approximately 225 million people (World Bank, 2007), Indonesia is a significant player in the world economy. However, in regards to CSR, Indonesia faces three major challenges: (1) a weak legal system; (2) lack of competent managers; and (3) a high percentage of low income families (Hill, 1996). Addressing the first challenge, Indonesia's weak legal system, as in many developing countries, the tools of civil society in Indonesia are structurally and legislatively weak. The government is always perceived negatively by its people due to rampant corruption and bribery (Kemp, 2001). "Bribes by firms in Indonesia arise principally from regulations -licenses and levies --imposed by local government officials," (Henderson \& Kuncoro, 2004, p.1). The government's poor image raises another concern. Many large Indonesian companies have Indonesian politicians on their board of directors in order to protect the business. The endemic culture of corruption is causing a widespread cynicism in a culture used to officials' dishonesty (Alatas, 1999). Consumers tend to disbelieve that companies will put legal, ethical and philanthropic aspects before economic obligations. 
Large business in Indonesia is marked by the presence of what have been labelled "conglomerates" that is, well-connected groups of business linked to Indonesia political elites-and large State Owned Enterprises (SOEs), which are bureaucratic corporations protected by the power of government and patronage (Kemp, 2001, p. 2).

Concerning the second challenge, lack of competent managers, CSR requires commitment, long-term thinking and vision from business managers. Indonesia has too few trained managers, especially in the area of CSR. Many local large businesses in Indonesia only promote those with political or family connections (Faulkner, 1995). Finally, concerning the last challenge, a high percentage of low income families, the majority of Indonesian people have a low income or salary. In 2007, Indonesia's Gross National Income per capital is only US $\$ 1,650.00$ / year with 47.1 percent of the expenses going toward food and nonalcoholic beverages (Euromonitor, 2006; World Bank, 2007). In that case, spending extra money to support socially responsible companies would become a difficult choice for many consumers in Indonesia.

\section{Hypotheses Development}

Based on Carroll's (1979) model which consists of (1) economic, (2) legal, (3) ethical and (4) philanthropic components and the previous literature review discussions, we developed our research hypotheses. Many Indonesian consumers are often unaware of the concept of CSR. They believe that the business of business is making a profit. The legal and ethical issues are considered less important as consumers realize that most businessmen can bend the law if necessary (Kemp, 2001). Finally, philanthropic practices would be considered the last option for a company to engage in. Carroll (1979) also suggested the following decreasing of importance: (1) legal, (2) ethical, (3) philanthropic. Thus, we suggest these following hypotheses:

H1 : Consumers in Indonesia will distinguish between the following types of corporate responsibilities: (1) economic, (2) legal, (3) ethical and (4) philanthropic. 
H2 : Consumers in Indonesia will place (a) economic responsibility higher than (b) legal, (c) ethical and (d) philanthropic responsibility.

H3 : Consumers in Indonesia will place corporate (b) legal, (c) ethical, (d) philanthropic responsibility in the following decreasing order of importance: (1) legal, (2) ethical and (3) philanthropic responsibility.

In most developing countries including Indonesia, people are experiencing lower income than their counterparts in the developed countries. In this situation, consumers will focus on buying more economical products rather than paying more to support a socially responsible company. Many consumers in developing countries have unpredictable income streams. They tend to purchase only what they need, and when they have the cash (Prahalad, 2005). Paying a higher price for supporting a socially responsible company would reduce their capacity to consume other products. Nevertheless, similar to consumers in the developed country, only if price and quality are similar, consumers are willing to switch brands to one associated with better CSR activities. Thus we suggest these following hypotheses:

H4 : Consumers in Indonesia will not be supportive of socially responsible businesses when shopping.

H5 : Consumers in Indonesia are willing to support CSR only if the product quality and price is similar.

\section{Methodology}

\section{Measure}

We conducted a survey using the scales developed by Maignan (2001, p. 62). The scales have been used to measure consumer's perception of CSR in China (Ramasamy \& Yeung, 2009). Maignan (2001) investigates consumers' readiness to support socially responsible organizations in France, Germany and the US. Maignan's (2001) paper also examines consumers' evaluations of the economic, legal, ethical and philanthropic responsibilities of the firm. Using the same scales we developed a three part questionnaire (i.e. A, B and C). In part A we measured consumers' evaluation of CSR with a total of sixteen 
attributes consisting of four groups of social responsibility (i.e. economic, legal, ethical and philanthropic responsibility) (Carroll, 1979). The scale measure $1=$ strongly disagree to 5=strongly agree. In part B, we measured consumers' support of responsible business practices. The respondents had to measure the following statements: (1) I would pay more to buy products from a socially responsible company; (2) I consider the ethical reputation of businesses when I shop; (3) I avoid buying products from companies that have engaged in immoral actions; (4) I would pay more to buy the products of a company that shows caring for the well-being of our society; (5) If the price and quality of two products are the same, I would buy from the firm that has a socially responsible reputation. The scale measure $1=$ never to $5=$ always. The last part of the questionnaires, part $\mathrm{C}$, gathers more information about the respondents.

The original measurement scales used a seven-point scale. However, in order to reduce confusion among respondents, we reduced the scale to a five-point scale (Lu \& Liu, 2000). All the items employed were first translated into Indonesian and then back-translated into English. Adjustments were made in cases where translations were incorrect (Brislin, 1976).

\section{Data collection}

As an exploratory research, we used a convenient sampling of undergraduate students from the faculty of pharmacy and psychology at Surabaya University, Indonesia. There are 443 usable surveys with 81.5 percent female and 18.5 percent male students. The student's ages range from 16 to 23 years old. The students come from various cities of the country. Students are deemed appropriate subjects for the research, since most students in Indonesia do not work, thus they have limited money to spend. This could represent the condition of most Indonesians which have limited income. Would they still support CSR? 


\section{Result and data analysis}

We ran principle component factor analysis using varimax rotation on the 16 attributes. The result shows that respondents are unable to regroup corporate social responsibilities according to their economic, legal, ethical and philanthropic nature (see table 1). When the factor loadings are \pm 0.50 or greater, they can be considered significant (Hair, 1998). The respondents can only clearly regroup the 'economic' responsibility of a company. If we look at respondents in developed countries, (e.g. French, Germany, and United States), they can clearly regroup the nature of corporate social responsibilities (Maignan, 2001). Even though the generally acceptable Cronbach's alpha lower limit is 0.70 , the Cronbach alpha value of 0.60 is still deemed acceptable in exploratory research (Hair, et al. 1998).

Nonetheless, it could be a sign of consumers' uncertainty toward many CSR issues. Thus, the result suggests no support for H1: Consumer in Indonesia will distinguish between the following types of corporate responsibilities: (1) economic, (2) legal, (3) ethical, and (4) philanthropic.

Table 1: Scale items and exploratory factor analysis of corporate social responsibilities

\begin{tabular}{|l|l|l|l|l|}
\hline & PHI & ECO & ETH & LEG \\
\hline I believe that business must: & & & & \\
\hline Participate in the management of public affairs (PHI) & $\mathbf{0 . 7 8}$ & 0.07 & 0.05 & 0.02 \\
\hline Help solve social problems (PHI) & $\mathbf{0 . 7 4}$ & -0.04 & 0.18 & -0.01 \\
\hline Play a role in our society that goes beyond the mere generation of profits (PHI) & $\mathbf{0 . 6 9}$ & 0.04 & -0.04 & 0.23 \\
\hline Be committed to well-defined ethics principles (ETH) & $\mathbf{0 . 5 6}$ & 0.17 & 0.32 & 0.13 \\
\hline Allocate some of their resources to philanthropic activities (PHI) & $\mathbf{0 . 5 3}$ & 0.03 & 0.31 & -0.18 \\
\hline Always submit to the principles defined by the regulatory system (LEG) & $\mathbf{0 . 5 2}$ & 0.10 & 0.42 & 0.29 \\
\hline Maximize profits (ECO) & -0.04 & $\mathbf{0 . 7 5}$ & -0.07 & -0.11 \\
\hline Always improve economic performance (ECO) & -0.03 & $\mathbf{0 . 7 4}$ & 0.02 & -0.12 \\
\hline Plan for their long term success (ECO) & 0.11 & $\mathbf{0 . 6 5}$ & -0.02 & 0.19 \\
\hline Control their production costs strictly (ECO) & 0.10 & $\mathbf{0 . 5 9}$ & 0.05 & -0.02 \\
\hline Ensure that the respect of ethical principles has priority over that of & & & & \\
\hline economic performance (ETH) & 0.10 & -0.11 & $\mathbf{0 . 7 9}$ & -0.09 \\
\hline Permit ethical concerns to negatively effect economic performance (ETH) & 0.18 & -0.07 & $\mathbf{0 . 7 8}$ & 0.01 \\
\hline Ensure that their employees act within the standards defined by law (LEG) & 0.35 & 0.37 & 0.37 & 0.09 \\
\hline Avoid compromising ethical standards in order to achieve corporate goals (ETH) & 0.14 & 0.27 & 0.35 & 0.13 \\
\hline Refrain from putting aside their contractual obligations (LEG) & 0.09 & -0.05 & 0.07 & $\mathbf{0 . 8 7}$ \\
\hline Refrain from bending the law even if this helps improve performance (LEG) & 0.07 & -0.01 & -0.04 & $\mathbf{0 . 8 5}$ \\
\hline & & & & \\
\hline Eigenvalue & 3.75 & 2.07 & 1.68 & 1.05 \\
\hline Cronbach alpha & 0.72 & 0.64 & 0.66 & 0.73 \\
\hline PHI phin
\end{tabular}

$\mathrm{PHI}=$ philanthropic responsibilities; ECO = economic responsibilities; ETH = ethical responsibilities; $\mathrm{LEG}=$ legal responsibilities 
Hypotheses $\mathrm{H} 2$ and $\mathrm{H} 3$ were tested using a series of repeated measures based on the four groups of CSR (i.e. PHI, ECO, ETH and LEG). The results show that economic responsibility has the highest overall mean (4.15), followed by philanthropic responsibilities (4.10), legal responsibilities (4.09) and ethical (3.84). These results show support for H2: Consumers in Indonesia will place (a) economic responsibility higher than (b) legal, (c) ethical and $(d)$ philanthropic responsibility. However the results do not show support for H3: Consumers in Indonesia will place corporate (b) legal, (c) ethical, (d) philanthropic responsibility in the following decreasing order of importance: (1) legal, (2) ethical, and (3) philanthropic responsibility. These findings can be explained from the previous literature review. It demonstrates that consumers in developing countries place economic responsibility as the first priority. This is similar to the belief many consumers in developed countries had when CSR was not yet developed. 'The social responsibility of business is to increase profits,' (Friedman, 1970, p. 32). In addition, the logical explanation of why respondents feel philanthropic responsibilities are more important than legal and ethical responsibilities is the existence of Indonesia's many social and economic problems, and the government's inability to solve them. Consumers are expecting corporations to assist government in solving these issues (Koestoer, 2007; Kuncoro, 2006). Furthermore, the possible explanation of why the legal and ethical responsibilities are considered less important is due to lack of trust of the current legal systems in developing countries (Kemp, 2001).

Hypothesis H4 \& H5 was also tested using repeated measures. A test of homogeneity of variance was also conducted and there are no significant differences among these groups. The repeated measures results suggest low support of CSR from consumers, with the exception of question five. The analyses show that: (1) I would pay more to buy products from a socially responsible company (Mean $=3.21$ ); (2) I consider the ethical reputation of businesses when I shop (Mean = 3.36); (3) I avoid buying products from companies that have 
engaged in immoral actions (Mean $=3.58$ ); (4) I would pay more to buy the products of a company that shows caring for the well-being of our society (Mean $=3.51)$. Questions number 5 shows the highest overall means compared to other responses. It shows support for H5; (5) If the price and quality of two products are the same, I would buy from the firm that has a socially responsible reputation (Mean $=4.14$ ); we summarize our findings in table 2 .

Table 2: Summary of study findings

\begin{tabular}{|l|l|l|}
\hline Hypothesis & Result & Short Interpretation \\
\hline H1 & Rejected & $\begin{array}{l}\text { Consumers in Indonesia are unable to distinguish } \\
\text { types of corporate social responsibilities }\end{array}$ \\
\hline H2 & Failed to be rejected & $\begin{array}{l}\text { Consumers in Indonesia place (a) economic } \\
\text { responsibility higher than (b) legal, (c) ethical and } \\
\text { (d) philanthropic responsibility }\end{array}$ \\
\hline H3 & Rejected & $\begin{array}{l}\text { Consumers in Indonesia place corporate (b) legal, } \\
\text { (c) ethical, (d) philanthropic responsibility in the } \\
\text { following decreasing order of importance: (1) } \\
\text { philanthropic responsibility (2) legal, and (3) ethical }\end{array}$ \\
\hline H4 & Failed to be rejected & $\begin{array}{l}\text { Consumers in Indonesia are not supportive of } \\
\text { socially responsible businesses when shopping }\end{array}$ \\
\hline H5 & Failed to be rejected & $\begin{array}{l}\text { Consumers in Indonesia are willing to support CSR } \\
\text { only if the product quality and price is similar }\end{array}$ \\
\hline
\end{tabular}

\section{Practical Implications}

These findings suggest that consumers in Indonesia are still unaware and unwilling to support CSR. Most people in Indonesia and other developing countries are struggling daily to afford many of the basic necessities, thus it is a logical conclusion that they would spend their money to buy the most affordable products, despite a company's high or low involvement in CSR activities. CSR is not yet a determining factor in buying a product from a company. This is the opposite finding of consumer perception in developed countries, where most consumers are willing to support CSR launched by corporations (e.g. Brown \& Dacin, 1997; Creyer \& Ross Jr, 1997; Du, Sen, \& Bhattacharya, 2008; Maignan, 2001). The result of this research, using respondents in developing countries, demonstrates that CSR research needs to be clarified. It is still a concept mainly applicable to developed countries. We now need to be careful before applying the concept of CSR strategy globally. Consumers might have different perceptions and responses. CSR might strongly be related to the economic, social 
and political condition of a country (Visser, 2008). However an interesting finding appears in this study. On question number five, when consumers have to buy similar products with the same price and quality, CSR could be the determining factor. They would buy from the firm that has a socially responsible reputation. This demonstrates that CSR could become a beneficial strategy to a company when they are in a competitive environment. However, we could carefully interpret that when another company offers lower prices, CSR strategy would no longer be attractive to these consumers.

\section{Limitation and Future Research}

There are some limitations in this research which could provide guidance for future research. First, this research was using a student sample as the respondents, which only represents a particular subgroup in Indonesia or developing countries, and in Indonesia there are various groups of consumers. In addition, 81.5 percent of the respondents were female. To ensure there was no gender biased, we ran a series of repeated measures using female and male gender separately. We were trying to test if there are significant differences between the two. We found there were no significant differences between the two. Secondly, this paper only looks at consumer perception and intention, thus there might be differences between consumers' intention and their actual behaviour to support CSR (Maignan, 2001). Thirdly, we do not differentiate the types of companies on the questionnaire (i.e. locally owned or foreign investment). Consumers might have different expectations and responses toward these companies.

Future research can look at several gaps: (1) Macro and micro level of CSR. A macro level can look at what really formed willingness or unwillingness to support CSR in various countries? At a micro level, we can look at how consumers of different income levels perceive companies' CSR efforts differently. There are various groups in developing countries that have higher income and more disposable income. Are these groups willing to support CSR or 
not?; (2) CSR adaptation of foreign companies in many of the developing countries. Many of the foreign companies are coming from Western countries with solid CSR applications. Do they reduce their CSR standards in order to operate successfully in developing countries?; (3) Different stakeholder treatments in developing countries. While further improvements of CSR in developing countries are increasing (Visser, 2007), Blowfield and Frynas (2005, p. 508) argue that 'consequently, the well-being of some groups [stakeholders] in developing countries may be jeopardized by the very pursuit of CSR'. What are the perceptions of consumers when they realize that the consequences of CSR adoption are not always benefiting the society; (4) Distinct forms of CSR in developing countries. Whilst the results of the study suggest that the consumer awareness of and support for CSR in Indonesia is relatively limited, Visser \& Macintosh (1998); Nelson (2004) suggest that CSR in developing countries may exist in different forms such as moral, ethical, religious and legal condemnation of irresponsible business practices. Do these values have the same weight as CSR concepts in the develop countries? All these issues can be further analysed for future research. 


\section{Reference}

Alatas, S. H. (1999). Corruption and The Destiny of Asia: Prentice Hall, Malaysia.

Beckmann, S. (2007). Consumers and Corporate Social Responsibility. Australasia Marketing Journal, 15(1), 27-36.

Berle, A. A., \& Means, G. C. (1948). The Modern Corporation and Private Property. New York: Macmillan.

Bhattacharya, C. B., \& Sen, S. (2004). Doing Better at Doing Good: When, Why, and How Consumers Respond to Corporate Social Initiatives. California Management Review, 47(1), 924.

Blowfield, M. (2003). Ethical Supply Chains in the Cocoal, Coffee and Tea Industries. Greener Management International, 43(Autumn: 15-24).

Blowfield, M. and Frynas, J. G. (2005). Setting New Agendas: Critical Perspectives on Corporate Social Responsibility in the Developing World. International Affairs, 81(3) 499-513.

Brislin. (1976). Translation: Application and research. New York: Joh Wiley/ Halstead.

Brown, T. J., \& Dacin, P. A. (1997). The Company and the Product: Corporate Associations and Consumer Product Responses. Journal of Marketing, 61(1), 68-84.

Carroll, A. B. (1979). A Three-Dimensional Conceptual Model of Corporate Social Performance. Academy of Management Review, 4(4), 497-505.

Carroll, A. B. (1991). The Pyramid of Corporate Social Responsibility: Toward the Moral Management of Organizational Stakeholders. Business Horizons, 34(4), 39-48.

Carroll, A. B. (1995). Stakeholder thinking in three models of management morality. In J. Nasi (Ed.), Understanding stakeholder thinking. Helsinki: LSR Publications.

Cone Corporate Citizenship. (2001). Retrieved: 10 November 2008. Source: www.coneinc.com.

Creyer, E. H., \& Ross Jr, W. T. (1997). The influence of firm behavior on purchase intention: do consumers really care about business ethics? Journal of Consumer Marketing, 14(6), 419432.

Du, S., Bhattacharya, C. B., \& Sen, S. (2007). Reaping relational rewards from corporate social responsibility: The role of competitive positioning. International Journal of Research in Marketing, 24(3), 224-241.

Du, S., Sen, S., \& Bhattacharya, C. B. (2008). Exploring the Social and Business Returns of a Corporate Oral Health Initiative Aimed at Disadvantaged Hispanic Families. Journal of Consumer Research, 35. 
Euromonitor. (2006). Indonesian household spending makes way for growth of non-food sector. Retrieve: 25 August 2008, Source:

http://www.euromonitor.com/Indonesian_household_spending_makes_way_for_growth of_non_food_sector.

Faulkner, G. (1995). Business Indonesia. Sydney: Business and Professional Publishing.

Friedman, M. (1970, September 13). The social responsibility of business in to increase its profits. New York Times Magazine, 32-33, 122, 124, 126.

Frynas, J. G. (2006). Corporate Social Responsibility in Emerging Economies. Journal of Corporate Citizenship, 24(Winter), 16-19.

Hair, J. F., Anderson, R. E., Tatham, R. L., \& Black, W. C. (1998). Multivariate Data Analysis. Upper Saddle River, New Jersey 07458: Prentice Hall.

Handelman, J. M., \& Arnold, S. J. (1999). The Role of Marketing Actions with a Social Dimension: Appeals to the Institutional Environment. Journal of Marketing, 63(3), 33-48.

Henderson, J. V., \& Kuncoro, A. (2004). Corruption in Indonesia, National Bureau of Economic Research Working Paper Series 10674.

Hill, H. (1996). The Indonesian Economy Since 1986: South East Asia's Emerging Giant. Cambridge: University Press, Cambridge.

Jamali, D. (2007). The Case for Strategic Corporate Social Responsibility in Developing Countries. Business \& Society Review (00453609), 112(1), 1-27.

Kemp, M. (2001) Corporate Social Responsibility in Indonesia: Quixotic Dream or Confident Expectation? Technology, Business and Society Programme Paper no. 6, Geneva. United Nations Research Institute for Social Development.

Koestoer, Y. (2007) Corporate Social Responsibility in Indonesia: Building internal corporate values to address challenges in CSR Implementation. Seminar on Good Corporate and Social Governance in Promoting ASEAN's Regional. Asean Secretariat, Jakarta, Indonesia.

Kuncoro, A. (2006) Corruption and Business Uncertainty in Indonesia. Asean Economic Bulletin.

Lichtenstein, D. R., Drumwright, M. E., \& Braig, B. M. (2004). The Effect of Corporate Social Responsibility Donations to Corporate-Supported Nonprofits. Journal of Marketing, $68,16-32$.

Lu, X., \& Liu, M. (2000). Adapting the Servqual Scale to China Hospitals Services. ICMIT, 204-208.

Maignan, I. (2001). Consumers' perceptions of corporate social responsibilities: A crosscultural comparison. Journal of Business Ethics, 30(1), 57. 
Maignan, I., \& Ferrell, O. C. (2000). Measuring Corporate Citizenship in Two Countries: The Case of the United States and France. Journal of Business Ethics, 23(3), 283-297.

Maignan, I., \& Ferrell, O. C. (2003). Nature of corporate responsibilities: Perspectives from American, French, and German consumers. Journal of Business Research, 56(1), 55.

Nelson, J. A. (2004) A Buddhist and Feminist Analysis of Ethics and Business. Development, 47(3) 53-60.

Orlitzky, M., Schmidt, F. L., \& Rynes, S. L. (2003). Corporate Social and Financial Performance: A Meta-analysis. Organization Studies (01708406), 24(3), 403-441.

Prahalad, C. K. (2005). The Fortune at the Bottom of the Pyramid. Upper Saddle River, NJ: Wharton School Publishing.

Prieto-Carrón, M., Lund-Thomsen, P., Chan, A., Muro, A. and Bhushan, C. (2006) Critical Perspectives on CSR and Development: What We Know, What We Don't Know, and What We Need to Know. International Affairs, 82(5) 977-987.

Quazi, A. M., \& O'Brien, D. (2000). An Empirical Test of a Cross-national Model of Corporate Social Responsibility. Journal of Business Ethics, 25(1), 33-51.

Ramasamy, B. \& Yeung, M. (2009) Chinese Consumers' Perception of Corporate Social Responsibility (CSR). Journal of Business Ethics, vol. 88, p119-132

Sankar, S., Bhattacharya, C. B., \& Daniel, K. (2006). The Role of Corporate Social Responsibility in Strengthening Multiple Stakeholder Relationships: A Field Experiment. Academy of Marketing Science. Journal, 34(2), 158.

Smith, N. C. (2003). Corporate Social Responsibility: Whether or How? California Management Review, 45(4), 52-76.

Snider, J., Paul, R. H., \& Martin, D. (2003). Corporate Social Responsibility in the 21st Century: A View from the World's Most Successful Firms. Journal of Business Ethics, 48(2), 175-187.

Uusitalo, O., \& Oksanen, R. (2004). Ethical consumerism: a view from Finland. International Journal of Consumer Studies, 28(3), 214-221.

Visser, W. \& Macintosh, A. (1998) A Short Review of the Historical Critique of Usury. Accounting, Business \& Financial History, 8(2) 175-89.

Visser, W. (2007). Developing Countries In W. Visser, D. Matten, M. Pohl \& N. Tolhurst (eds.), The A to Z of Corporate Social Responsibility. London: Wiley, 154-157.

Visser, W. (2008) Corporate Social Responsibility in Developing Countries. In Crane, A., McWilliams, A., Matten, D., Moon, J. and Siegel, D. (eds). The Oxford Handbook of Corporate Social Responsibility. Oxford, Oxford University Press, pp. 473-479.

World Bank. (2007). World Development Indicators. Accessed: 16 August 2008, Source: www.web.worldbank.org. 
Zulkiflli, N., \& Amran, A. (2006). Realising Corporate Social Responsibility in Malaysia: A View from the Accounting Profession. Journal of Corporate Citizenship, 24(Winter: 101-14). 